\title{
PROBLEM REPREZENTACJI W NAUCE - OBSZARY NIEZBADANE
}

\section{WPROWADZENIE}

Wydawałoby się, że problem reprezentacji w nauce, a dokładniej: rzeczywistości w poznaniu naukowym, jest obecnie wszechstronnie przebadany, a nawet - sądząc $z$ nadzwyczaj obszernej literatury przedmiotu — można by wnioskować, że filozofia weszła w fazę przesytu tą problematyką, że jest ona już wyeksploatowana i nie da się nic dodać do zbioru koncepcji reprezentacji rzeczywistości w wiedzy naukowej. Ta konstatacja nie jest jednak zasadna. W problematyce reprezentacji można wyróżnić trzy następujące obszary filozoficznie istotne ${ }^{1}$, a dotychczas szerzej niebadane, poza pojawiającymi się sporadycznie niszowymi przyczynkami, niezauważanymi w głównych trendach.

Po pierwsze, w badaniach reprezentacji pomija się nauki techniczne i informatyczne i w związku z tym - co tu istotne — nie objaśnia się w ogóle swoistości reprezentowania $w$ tych naukach. Uwagę poświęca się prawie wyłącznie, a w każdym razie głównie zagadnieniu reprezentowania $\mathrm{w}$ deskrypcyjno-eksplanacyjnych (inaczej teoretycznych) naukach empirycznych. Tymczasem dwa pomijane rodzaje nauk są niezmiernie ważne nie tylko dlatego, że kształtują obecnie ludzki świat, ale też ze względu filozoficznego, w tym z powodu specyfiki występujących w nich relacji reprezentacji. W naukach technicznych i komputerowych reprezentowanie ma inne podstawowe właściwości

Dr MARIUSz MAZureK - Instytut Filozofii i Socjologii PAN; adres do korespondencji: ul. Nowy Świat 72, 00-330 Warszawa; e-mail: mmazurek@ifispan.edu.pl; ORCID: https://orcid.org/00000002-9646-6897.

${ }^{1}$ Wskazuję problemy, które warto podjąć, i częściowo uzasadniam, dlaczego są one ważne. Nie jest to całościowe, wyczerpujące rozpoznanie problematyki, ale fragmentaryczne. Także literatura przedmiotu, do której się odnoszę, nie jest w pełni reprezentatywna. 
niż reprezentowanie w naukach empirycznych, skupiających uwagę na zadaniach wyłącznie poznawczych, w tym głównie na konstruowaniu teorii naukowych dla badanych dziedzin rzeczywistości empirycznej. Z pewnością nie da się przenieść koncepcji reprezentowania w naukach empirycznych do nauk dwóch pozostałych typów. Ma to tym większe znaczenie, że relacja reprezentowania jest bazowym czynnikiem poznania według większości koncepcji poznania, także idealistycznych, w tym konstruktywistycznych ${ }^{2}$, z pominięciem jednak pragmatystycznych — ze względu na rozległość problemu nie można tego stwierdzenia $\mathrm{w}$ tym tekście uzasadniać.

Po drugie, w badaniu reprezentacji nie rozróżnia się specyfiki reprezentacji w obszarze teoretycznym oraz praktycznym nauk empirycznych, takich jak m.in. socjologia, ekonomia, politologia, kulturoznawstwo. W związku $\mathrm{z}$ tym dosyć powszechna jest tendencja do przenoszenia koncepcji reprezentowania z opisowo-wyjaśniających (teoretycznych) nauk empirycznych, głównie przyrodniczych, do obszaru praktycznych zastosowań nauk empirycznych, czyli do tzw. nauk stosowanych. Ilustracją tego stanu rzeczy jest powoływanie się na koncepcje reprezentowania Nancy Cartwright, konstruowanych z myślą o naukach przyrodniczych, w rozważaniach dotyczących ekonomii i tworzonych $w$ niej modeli ${ }^{3}$. Tymczasem już nawet nierozbudowane analizy pokazują, że takie przenoszenie jest wątpliwe ${ }^{4}$. W naukach przyrodniczych relacja reprezentowania jest inna niż w tzw. stosowanej ekonomii, projektującej procesy ekonomiczne, które w momencie projektowania nie istnieją, a są dopiero tworzone „mentalnie”, a w związku z tym użycie koncepcji skrzynki narzędziowej czy koncepcji bajki oferowanych przez Cartwright do ujęcia modelowania w ekonomii trzeba traktować $\mathrm{z}$ najwyższą ostrożnością i licznymi wątpliwościami.

Po trzecie, w badanym obszarze odnoszącym się do nauk empirycznych koncepcje reprezentacji mają uderzająco podobny do siebie charakter, w dodatku - wydaje się — filozoficznie naiwny i pod pewnymi względami błędny.

Wspomnieć też trzeba, dla jasności, że wypracowana i badana obecnie problematyka reprezentacji sytuuje się w dwóch obszarach: w filozofii nauk

\footnotetext{
${ }^{2} \mathrm{~W}$ koncepcjach idealistycznych, w tym konstruktywistycznych, inny niż w koncepcjach realistycznych jest człon reprezentowany: nie jest nim obiekt w przyrodzie lub społeczeństwie itp., lecz obiekt idealny lub konstrukt wytworzony przez podmiot poznania.

${ }^{3}$ Przykłady takich rozważań można znaleźć m.in. w: HardT 2014, 13-37, HARDT 2016, 147-174).

${ }^{4}$ Zob. Morgan i KnUUtTila 2012, 49-87 oraz Hardt 2018, 41-70.
} 
empirycznych oraz $\mathrm{w}$ teoriach umysłu, rozwijanych głównie w kognitywistce $^{5}$ i w filozofii, która czerpie z badań kognitywistycznych. W pierwszym obszarze kwestia reprezentacji jest rozumiana jako reprezentowanie rzeczywistości w wiedzy naukowej, natomiast w drugim — jako reprezentacja rzeczywistości w umyśle podmiotu. Te dwie główne badane obecnie relacje reprezentacji nie są niezależne, a jednak traktuje się je odrębnie. Drugi typ badań formułuje najczęściej materialistyczne, konkretniej neurofizjologiczne koncepcje umysłu, utożsamiające umysł z mózgiem, a operacje i wszelką aktywność umysłową z operacjami neurofizjologicznymi w mózgu. Materialistyczne koncepcje umysłu w najnowszej filozofii umysłu, w dużym zakresie znaturalizowanej (czerpiącej głównie z kognitywistyki i neurofizjologii teoretycznej), mają cząstkową tylko przydatność jako podstawa czy element koncepcji reprezentacji rzeczywistości w wiedzy naukowej. Dzieje się tak głównie dlatego, że koncepcje te definiują wiedzę, w tym wiedzę naukową, inaczej niż w filozofii nauki. Filozofowie nauki rozumieją wiedzę jako wytwór obiektywny — podzbiór zdań pewnego języka lub/i jako zbiór obiektywnych modeli, także modeli niejęzykowych. Według kognitywistów wiedza należy do umysłu, jest zbiorem stanów mentalnych (np. Paul Thagard ${ }^{6}$, Jerry Fodor), a więc musi mieć charakter subiektywny lub przynajmniej subiektywny aspekt. Wynikiem funkcjonowania umysłu są stany mentalne indywidualnego podmiotu. Koncepcje te nie pokazują, jak ze stanów neurofizjologicznych, obiektów w mózgu, wytwarzana jest wiedza, czyli jak przekształca się neurofizjologiczne stany $\mathrm{w}$ pojęcia i formuły języka; jak z prywatnych obiektów, jakimi są te stany, tworzona jest wiedza obiektywna, to znaczy, na czym polega proces desubiektywizacji (równoważnie obiektywizacji) stanów mentalnych indywidualnego podmiotu. Tak więc w sumie pomiędzy reprezentowaniem a tym, jak ono jest ujmowane w filozofii umysłu, reprezentowaniem mentalnym uwidacznia się pęknięcie, którego obecnie nie sposób usunąć. A niewątpliwie warto byłoby to zrobić, aby utworzyć teorię poznawania uwzględniającą wszystkie jego etapy — od działań podmiotu, który poznaje, w tym jego mózgu zaangażowanego w procesy poznawcze, po wytworzenie obiektywnej wiedzy.

\footnotetext{
${ }^{5}$ Kognitywistyka, od początku dziedzina głęboko znaturalizowana, ewoluuje w stronę nauk empirycznych i obecnie jest już, wydaje się, zbiorem nauk empirycznych, które zajmują się procesami poznawczymi oraz elementami w nich uczestniczącymi (podmiotem poznania traktowanym naturalistycznie, głównie z perspektywy psychologicznej i neurofizjologicznej, a także językiem prezentującym wyniki poznawania). Odrębność kognitywistyki od filozofii powiększa się.

${ }^{6}$ Zob. THAGARD 2005, wyd. 2.
} 
W tym artykule zajmuję się jedynie reprezentacją w nauce, rozumianą jako relacja między wiedzą naukową a rzeczywistością; pomijam natomiast zagadnienie reprezentacji mentalnej. Poniżej omówię nieco szerzej trzy wspomniane obszary, prawie zupełnie niedostrzegane w filozoficznych badaniach (dokładniej: w szeroko traktowanej filozofii nauki) kwestii reprezentacji jako relacji wiedzy do rzeczywistości.

\section{REPREZENTACJA W NAUKACH EMPIRYCZNYCH. KREACYJNY MARAZM}

Rozważania dotyczące relacji reprezentacji w naukach empirycznych są najważniejszą częścią badania poznania naukowego w dominującej linii najnowszej filozofii nauki. Relację tę traktuje się jako fundament epistemologicznych koncepcji nauki, uznając, że wraz z modelami ustanawia ona naturę poznania naukowego. Badania takie - koncentrujące uwagę na relacji reprezentowania i modelach reprezentujących rzeczywistość — znajdują się pozornie w stanie dynamicznego rozkwitu. Mamy obfitość prac i rozważań dotyczących tej problematyki. Są wśród nich i case studies $^{7}$, i próby wiązania kwestii reprezentacji $\mathrm{z}$ innymi problemami ${ }^{8}$, i klasyfikacje porządkujące dotychczasowe osiągnięcia (m.in. prace Danieli Bailer-Jones ${ }^{9}$ czy Brandona Boescha ${ }^{10}$ oraz klasyfikacje ważne w polskiej literaturze przedmiotu $^{11}$ - Władysława Krajewskiego ${ }^{12}$ i Ryszarda Wójcickiego ${ }^{13}$ ).

\footnotetext{
${ }^{7}$ Na przykład CARTwright 1999, 241-281.

${ }^{8}$ HuMPHREYS I IMBERT 2013.

${ }^{9}$ BAILER-JONES 2009.

${ }^{10}$ BOESCH 2018.
}

${ }^{11} \mathrm{~W}$ porównaniu z koncepcjami, w których podstawową kategorią jest model semantyczny, do których polscy filozofowie nauki i logicy (przede wszystkim Alfred Tarski, Roman Suszko, Marian Przełęcki, Ryszard Wójcicki i nieco później Adam Nowaczyk oraz Elżbieta Kałuszyńska) wnieśli ważny wkład, problematyka modeli niesemantycznych w polskiej literaturze przedmiotu (w zestawieniu z dokonaniami w relewantnej literaturze światowej) jest badana niezbyt rozlegle. Koncepcje modeli semantycznych tworzą odrębną linię badań. Od połowy lat osiemdziesiątych podejście do modeli zmieniło punkt ciężkości. W centrum uwagi znalazł się problem reprezentacji. Jedno z podstawowych pytań tego trwającego do dziś etapu badań w filozofii nauki, badań, które zmieniły też problematykę dotyczącą modeli brzmi: Jak modele reprezentują rzeczywistość? Por. ZeIDLER 2013. Znane są też prace, które podejmują problem reprezentacji, ale zupełnie inny — np. problem reprezentacji świata w neurofizjologicznych stanach mózgu, które są stanami indywidualnego podmiotu (ZAHORODNA 2015); w inżynierii ontologicznej, metod i narzędzi reprezentacji wiedzy (GocZYŁA 2011).

${ }^{12}$ KRAJEWSKI 1996. 
Większość badaczy tego zagadnienia posiłkuje się — co naturalne i nawet wymagane - nawzajem swymi wynikami, pracuje w tym samym środowisku intelektualnym i formułuje, co $\mathrm{w}$ tej sytuacji nie dziwi, podobne poglądy, choć trudno mówić tu o jednej szkole w jej tradycyjnym rozumieniu. Grupę filozofów i teoretyków nauki szczególnie ze sobą powiązanych tworzą badacze skupieni do pierwszej dekady naszego wieku wokół Nancy Cartwright (są to jej uczniowie: Mauricio Suárez, Roman Frigg, Gabriele Contessa, Martin Thomson-Jones, a także współpracownicy: Stephan Hartmann, Mary Morgan, Margaret Morrison, Stathis Psillos).

Jak zostało wspomniane, filozofowie zajmujący się problematyką reprezentacji w różnych intelektualnych środowiskach od lat osiemdziesiątych ubiegłego wieku tworzą koncepcje do siebie podobne, w dominującej części oparte na jednej idei, głoszącej mianowicie, że reprezentowanie jest podobieństwem, najczęściej sprowadzanym do izomorfizmu ${ }^{14}$. Do tej grupy należą m.in. Anouk Barberousse i Pascal Ludwig (Models as Fictions, 2009), Craig Callender, Jonathan Cohen (There Is No Special Problem about Scientific Representation, 2005), Nancy Cartwright (How the Law of Physics Lie, 1983; The Tool Box of Science, 1995; The Dappled World. A Study of the Boundaries of Science, 1999), Gabriele Contessa (Representing Reality, 2007), Newton da Costa, Steven French (Science and Partial Truth: A Unitary Approach to Models and Scientific Reasoning, 2003), Stephan Hartmann (Models as a Tool for Theory Construction: Some Strategies of Preliminary Physics, 1995), Demetris Portides (Seeking Representations of Phenomena: Phenomenological Models, 2011), Roman Frigg (Models and Representations: Why Structures are not Enough, 2002), Bas van Fraassen (Scientific Representation: Paradoxes of Perspective, 2008) ${ }^{15}$, Ronald N. Giere (Explaining Science. A Cognitive Approach, 1988), Mary S. Morgan, Margaret Morrison (Models as Mediating Instruments, 1999), Nancy Nersessian (Model-based Reasoning in Conceptual Change, 1999), Maurizio Suárez (Scientific Representation: Against Similarity and Isomorphism, 2003). Rozstrzygnięcia proponowane nie tylko przez wymienionych filozofów są na różne sposoby ostrożnie modyfikowane, lecz nie pojawiają się istotne nowe

\footnotetext{
${ }^{13}$ WóJCICKI 1994.

${ }^{14}$ Izomorfizm jest szczególnym typem podobieństwa (izomorfizm to identyczność struktur).

${ }^{15}$ Bas van Fraassen w swoich wcześniejszych pracach pisał o modelach semantycznych w ich specyficznym, nieteoriomnogościowym rozumieniu, nie opierając się i w ogóle nie przywołując teorii modeli Tarskiego, w której te modele są osadzone. W 2008 r. wydał książkę Scientific Representation, w której m.in. analizuje rozlegle identyfikowanie relacji reprezentacji z relacją podobieństwa.
} 
koncepcje, tzn. zrywające z osiowym schematem myślenia o reprezentacji jako o takim lub innym podobieństwie pomiędzy wiedzą a rzeczywistością. „Rzeczywistość” jest tu — na ogół milcząco — rozumiana jako całość przedmiotów fizycznych, przeważnie też milcząco utożsamianych z bytami. Filozofowie optujący za reprezentacją jako naczelną relacją w poznaniu są więc realistami - najczęściej zakamuflowanymi realistami bezpośrednimi, często zwanymi naiwnymi (jednym z wyjątków jest Giere), w każdym razie stronią od tak modnego obecnie konstruktywizmu ${ }^{16}$.

Rekapitulując, mimo „wysypu” rozstrzygnięć mówiących, jaka jest reprezentacja, i poświęconej temu problemowi bogatej literatury badania są w stanie zastoju - ze względu na swą małą kreatywność, brak nowych idei czy ze względu na jednakowy charakter różnych ujęć. Można by stwierdzić, posiłkując się pojęciem Thomasa Kuhna, że badania te znajdują się w fazie „filozofii normalnej”, tyle że filozofia „normalna”, w odróżnieniu od nauk „normalnych” (w sensie Kuhna), to filozofia w defensywie, tracąca twórczy rozmach; filozofia, która jest w pewnym sensie wyczerpuje się, a nawet jest epigońska. Wyznacza ona określone idee, standardy myślenia, poza które nie należy wychodzić i które można tylko interpretować czy wyrażać za pomocą różnych pojęć, a także dobudowywać - lecz jest pozbawiona wolności myślenia, która stanowi jej naczelny atrybut.

Podobieństwo poglądów wiążące się ze swoistym kolapsem kreatywności jest być może spowodowane tym, że problemem reprezentacji zajmuje się ostatnio - jak już wspomniałem - stosunkowo niewielka grupa powiązanych ze sobą, skupionych wcześniej wokół Cartwright, filozofów, którzy silnie na siebie oddziałują, choć nie występują jako szkoła ${ }^{17}$. Pewną popularnością $\mathrm{w}$ pracach tego środowiska cieszą się ponadto, nienależący do niego, Ronald N. Giere i Bas van Fraassen. Natomiast prace próbujące forsować inne podejścia oraz historia tego problemu w filozofii - niezmiernie ważna dla jego zgłębienia - są prawie kompletnie ignorowane przez tę grupę, zadającą standardy myślenia o reprezentowaniu. Być może ma tu znaczenie np. intelektualna moda czy skłonność filozofów do badań w jednym narzucanym stylu.

W każdym razie w efekcie kształtowania się we wzajemnych oddziaływaniach wspólnego schematu myślenia o reprezentacji tworzone są obecnie koncepcje do siebie podobne, niewyłamujące się z przyjętych schematów.

\footnotetext{
${ }^{16}$ Chociaż jest możliwe uzgodnienie reprezentacjonistycznej koncepcji wiedzy z konstruktywizmem i z idealizmami, np. z idealizmem subiektywnym. Zob. CZARNOCKA 2019.

${ }^{17}$ Por. np. Frigg 2010, 97-138, Contessa 2007, 1-183 i SuÁrez 2010, 91-101.
} 
Filozofowie „mainstreamowi” głównie dyskutują elementy swoich koncepcji reprezentacji, ostrożnie je modyfikują, nie naruszają jednak ich osiowej idei, traktującej o podobieństwie, w tym głównie o izomorfizmie. Przy tym „podobieństwowe" koncepcje reprezentowania kryją się pod różnymi nazwami, np. mówi się o wiedzy lub modelach reprezentujących jako o bajkach (Nancy Cartwright), fikcjach literackich (Roman Frigg), obiektach idealizacyjnych (Demetris Portides), obiektach zastępczych, dublerach (Gabriele Contessa), mediatorach (Mary Morgan, Margaret Morrison), układach brakujących (Uskali Mäki, Martin Thomson-Jones). Na marginesie należy wspomnieć, że ideę podobieństwa struktur (a więc izomorfizmu) wysunął już Bertrand Russell w latach dwudziestych XX wieku (o czym w literaturze przedmiotu współcześni badacze problematyki nie wspominają), a więc nie można jej uznać za ideę całkiem nową, lecz tylko reaktywowaną ${ }^{18}$. Jej słabsze wersje obejmują izomorfizm częściowy (Newton da Costa i Steven French) lub głoszą, że relacja reprezentowania jest podobieństwem aspektowym i co do stopnia (Ronald N. Giere).

Niektórzy autorzy odżegnują się wprawdzie w swoich deklaracjach od identyfikowania reprezentacji jako podobieństwa (np. Frigg w koncepcji fikcji literackiej ${ }^{19}$ ), lecz w istocie często podobieństwo zakładają, a może, należałoby powiedzieć, nieświadomie przemycają. Fikcje literackie opowiadają o świecie wyobrażonym, o wyobrażonych postaciach, sytuacjach itp. Przedmioty tekstu literackiego (fikcyjne sytuacje, zdarzenia, postaci) są identyczne $\mathrm{z}$ postaciami pojawiającymi się $\mathrm{w}$ świecie przez autora fikcji wyobrażonym: to, co literat tworzy, istnieje w świecie, który zakłada (chociaż ten świat nie jest częścią przyrody ani częścią realnego społeczeństwa itp.). Relacja między np. postaciami, sytuacjami świata fikcji a postaciami i sytuacjami $\mathrm{w}$ świecie przez autora wyobrażonym jest identycznością: literat tworzy mentalnie świat fikcyjny i zaludnia go — dowolnie - tymi właśnie obiektami, które wymyślił, które ulokował w tym świecie, a które istnieją tylko w jego wyobrażeniach. Jeśli reprezentacja jest tu pojmowana jako relacja zdań fikcji literackiej do świata wyobrażonego, to oczywiście o podobieństwie nie może być mowy, ale Frigg nie mówi, jaka ma być ta relacja, i przede wszystkim nie określa, jaki stosunek ma jego cała wymyślona koncepcja do procesów zachodzących w realnej nauce - jak fikcja dotyczy świata empirycznego, realnie istniejącego. Jeśli zaś Friggowi chodziło o relację postaci i sytuacji przedstawionych $\mathrm{w}$ tekście do postaci i sytuacji

\footnotetext{
${ }^{18}$ Zob. analizy w CZARNOCKA 2009, m.in. rozdz. I.

${ }^{19}$ Frigg 2010, 97-138.
} 
realnych, istniejących w rzeczywistości przyrodniczej lub społecznej, to wątpliwości się tu szybko mnożą. Po pierwsze, Frigg co najmniej upraszcza zawikłaną kwestię, twierdząc, że między obiektami istniejącymi a nieistniejącymi nie zachodzi podobieństwo. Po drugie, jeśli tak by było (z tego właśnie powodu, że obiekt reprezentujący nie istnieje w przyrodzie, jest bajką), to zupełnie nie wiadomo, jak wtedy funkcjonuje nauka, jaki sens ma tworzenie bajek o rzeczywistości, zwłaszcza że Frigg nie podaje, jaką relacją — skoro nie podobieństwem - jest reprezentacja.

Idea głosząca, że relacja reprezentowania jest podobieństwem, w szczególności izomorfizmem, ma niepokojące wady, których nie da się wyrugować, bo tkwią one w samym centrum ,podobieństwowej” koncepcji reprezentacji ${ }^{20}$. Kopiujący realizm, dawniej zwany naiwnym lub wulgarnym, implikowany przez ,podobieństwowe" modele reprezentacji jest tu pierwszym narzucającym się kłopotem - kłopotem, gdyż filozofia poznania dawno zdezawuowała tego typu ujęcia poznania. Przywołam tu najoczywistszy argument, ukazujący wadliwość takiego ujęcia. Według „podobieństwowych" koncepcji reprezentacji wiedza ma być podobna do rzeczywistości, a więc tylko niektóre własności jednej i drugiej mogą być identyczne. Trudno jednak wykazać, że zdania albo ich układy są podobne do obiektów w rzeczywistości, tj. że układy zdań mają niektóre właściwości takie same jak obiekty reprezentowane albo że jedne i drugie mają taką samą strukturę. Wystarczy bowiem porównać dowolne napisane zdanie z obiektem, o którym to zdanie coś mówi, żeby uświadomić sobie, że o żadnym izomorfizmie, homomorfizmie czy podobieństwie nie może być mowy ${ }^{21}$.

Ten zarysowany jedynie stan rzeczy skłania do zastanowienia się i przebadania, czy takie powszechnie niemal przyjmowane identyfikowanie reprezentacji powinno być dalej utrzymywane, czy nie powinno się od niego raczej odchodzić i formułować inne założenia i hipotezy dotyczące natury i charakteru relacji reprezentowania, a następnie podejmować badania, które przełamywałyby jednostronność wizji „podobieństwowych” i wskazywałyby nowe drogi ujmowania reprezentacji poprzez w ogóle odejście od takich wizji, a nie tylko poprzez — jak to ma miejsce dotychczas w dominującym obszarze - ich osłabianie, „zmiękczanie” podobieństwa do relacji nieco słabszej, jednak takiego samego typu (aspektowe i do pewnego stopnia podobieństwo u Ronalda N. Giere’a, częściowy izomorfizm według Newtona da Costy i Stevena Frencha, homomorfizm Jana Woleńskiego).

\footnotetext{
${ }^{20}$ Wykazywałem to w swojej monografii MAZUREK 2017.

${ }^{21}$ Inne argumenty można znaleźć w CZARNOCKA 2019 i CZARNOCKA 2009, część II.
} 


\section{REPREZENTOWANIE W NAUKACH TECHNICZNYCH}

Problem reprezentacji $\mathrm{w}$ naukach technicznych, które są teoretycznymi podstawami wdrażanych technologii, nie tylko - jak wspomniałem - nie jest szerzej współcześnie badany, lecz także na dobrą sprawę nie był nawet w ogóle dostrzeżony jako odrębny, ważny, wręcz fundujący ${ }^{22}$. Jest tak, mimo że o technologii i technice $\mathrm{w}$ filozofii ciągle się debatuje ${ }^{23}$, włączając je również do filozofii kultury (technika jest jedną z dominant współczesnej kultury, w najszerszym jej rozumieniu), filozofii polityki i badań nad nauką (science studies). Filozofowie nauki poprzestają na sporadycznych uwagach, oferowanych przeważnie na marginesach innych rozważań. Tymczasem zagadnienie to jest istotne, gdyż — jak można twierdzić — nie stanowi rozszerzenia kwestii relacji reprezentacji w naukach empirycznych, ale zawiera ważne i specyficzne zagadnienia filozoficzne na styku koncepcji twórczości ontologii i epistemologii, m.in. tworzenia rzeczywistości czy modusu istnienia tworzonych obiektów (artefaktów materialnych). Ponadto kwestia reprezentacji w tych naukach jest rdzeniem odsłaniającym naturę tych nauk i specyfikę kształtowania przez nie ludzkiego świata.

Problem ten był podnoszony przez starożytnych Greków (Heraklit, Demokryt, Platon i Arystoteles), którzy techne definiowali jako tworzenie artefaktów przy użyciu imitacji. W starożytności Platon, a przede wszystkim Arystoteles, wyróżniał nauki pojetyczne: technikę i łączył ją ze sztuką w jedną grupę aktywności wytwórczej. Arystoteles o technice niewiele pisał, ale zaprzeczał poglądowi Platona opartemu na pojęciu mimēsis, głoszącemu, że artefakty techniczne (czyli obiekty wytworzone przez człowieka różnymi technikami) są „odbiciami” rzeczy w przyrodzie ${ }^{24}$. Jest to najstarszy dwugłos w sprawie relacji reprezentacji mówiący o technice. Kwestia ta - choć wspominana jeszcze w średniowieczu i na początku ery nowożytnej — obecnie została zapomniana. Współcześnie technikę bada się w filozofii głównie ze względu na jej skutki społeczne ${ }^{25}$, natomiast stosunkowo mało mówi się o naturze tych nauk, o ich związkach z naukami teoretycznymi i różnicach między obydwoma typami nauk. Rozstrzygnięcia kwestii reprezentacji w naukach

${ }^{22}$ Zob. Franssen, Lokhorst i Poel 2018), zwł. rozdz. 2.5: Metaphysical Issues: The Status and Characteristics of Artifacts). Zob. także: Woolgar 2002, Woolgar, Lynch, Coopmans, i Vertesi 2014.

${ }^{23}$ Zob. np. РітT 1999.

${ }^{24}$ Zob. np. SCHUMMER 2001, 105-120.

${ }^{25}$ Zob. np. Galimberti 2009, 3-17; Gehlen 1980. 
technicznych są konieczne dla zrozumienia, czym technika w ogóle jest, odnoszą się do związku między człowiekiem, jego wytworami a rzeczywistością (i w sensie metafizycznym, i światem wytworzonym przez człowieka). Bez ujęcia tej relacji nie można zrozumieć techniki, a także funkcji, jaką odgrywa w ludzkim świecie. A to właśnie technika wpływa - co jest truizmem - w olbrzymim stopniu na to, jaki jest współczesny świat.

W najprostszej i najlapidarniejszej interpretacji nauki techniczne są naukami, które wytwarzają nowe „sztuczne” obiekty, to jest artefakty, przekształcając przy tym świat, w którym żyjemy: przyroda zaludnia się artefaktami, obiektami początkowo obcymi, nienależącymi do pierwotnego jej wyposażenia, a następnie albo oswajanymi, albo prowadzącymi do destrukcji pierwotnego środowiska człowieka. W każdym razie przyroda zmienia się na różne sposoby poprzez ingerencję w nią techniki. Zmienia się ludzki habitat, stosunki społeczne, w tym relacje międzyludzkie, a także sam człowiek, przede wszystkim zaś jego świadomość.

Już powyższe banalne stwierdzenia zapowiadają odmienność reprezentacji w naukach technicznych względem nauk empirycznych, o charakterze teoretycznym. W naukach technicznych najpierw - posiłkując się wiedzą techniczną, ufundowaną $\mathrm{z}$ reguły w wiedzy teoretycznej - tworzy się wyobrażenia obiektu (inaczej: idee, modele, projekty, prototypy myślowe itp.), a następnie te wyobrażenia (idee) są aktualizowane. Aktualizowanie polega na „urzeczywistnianiu” 26 , a konkretniej - na materializowaniu idei, tzn. na wytwarzaniu z nich artefaktów, czyli w tym przypadku obiektów materialnych. Artefakty są materialnymi realizacjami idei wytworzonych przy użyciu wiedzy technicznej ${ }^{27}$. Pierwotny status ontyczny przedmiotów techniki to status niematerialnych idei, nierzeczywistych, w sensie nienależących do przyrody. Stosuję tu podwójne znaczenie słowa „idea” w naukach technicznych: jest to i wiedza, którą się projektuje dla uformowania zamysłu artefaktu, i sam niematerialny przedmiot tej wiedzy. Idee tworzone przez podmiot nauk technicznych, obiekty niematerialne, są w pierwszej fazie subiektywnymi wytworami podmiotu, a następnie się je obiektywizuje. Powstają wtedy obiektywne i niematerialne przedmioty wiedzy technicznej. Można powiedzieć, że idee pierwotnie istnieją w świecie Platońskich idei

\footnotetext{
${ }^{26}$ Słowo „urzeczywistnianie” biorę w cudzysłów, ponieważ idee też są rzeczywiste w niektórych metafizykach, m.in. wszystkich typu platońskiego.

${ }^{27} \mathrm{O}$ artefaktach pisze m.in. HiLIPEN 2018. Inaczej status artefaktów interpretują: PRESTON 2018; Franssen i Kroes 2014, 63-84; Franssen, Kroes, Reydon i Vermaas 2014; Thomasson 2007, 52-73.
} 
lub - przy jednej $\mathrm{z}$ dopuszczalnych interpretacji — w trzecim świecie Poppera. Idea, będąca elementem wiedzy lub jej niematerialnym przedmiotem, przedstawia obiekt, który nie istnieje $\mathrm{w}$ momencie jej tworzenia, a jest obiektem, bytem potencjalnym albo czystą formą w sensie formowanym już przez filozofów greckich, głównie Arystotelesa (o czym poniżej).

Można wyjaśniać tworzenie artefaktu inaczej, a mianowicie opierając się na Arystotelesowskiej metafizyce. Jej podstawą są kategorie formy i materii, „substancji i przypadłości, istnienia $\mathrm{i}$ istoty, a więc to, co jest determinujące i determinowane, podporządkowujące i podporządkowane, rzeczywiste i możliwe w konkretnym bycie" ${ }^{28}$. Posługując się tymi kategoriami, można powiedzieć, że w naukach technicznych najpierw tworzy się czystą formę (czyli to, co możliwe, istotę, zbiór przypadłości) obiektu, który nie istnieje, a więc nie jest bytem w sensie Arystotelesa. To dopiero podmiot powołuje byt do istnienia, czyli łączy istotę (potencję) z materią, możliwe z potencją. To podmiot sprawia, że czysta forma jest dołączana do materii. Wynikiem jest byt materialny - artefakt, nowy, obcy wobec przyrody, ale włączony do niej i od momentu zaistnienia stanowiący jej element.

Idee, o których tu mowa (modele przedmiotów nieistniejących w świecie przyrody), są materializowane, inaczej: robione, wytwarzane. Trafne jest tu odwołanie się do Platońskiego i Arystotelesowskiego pojęcia poiessis. Platon uznaje przyrodę za wynik poiēsis: przyroda jest „zrobiona” z idei przez Demiurga. Można powiedzieć, przez analogię, że w technice dokonuje się aktualizowanie idei przez ludzki podmiot, który jest, na podobieństwo Platońskiego Demiurga, stworzycielem nowych obszarów świata. Aktualizowanie jest działalnością typu poiēsis, polega na robieniu w sensie Platońskim i Arystotelesowskim z idei, inaczej na przekształcaniu idei w materialne artefakty. Model obiektu (idea) jest czystą formą artefaktu, natomiast artefakt jest efektem aktu pojetycznego przeprowadzanego na idei.

Artefakty są materializacjami i wobec tego też naocznymi ekspresjami idei wypracowanych w naukach technicznych. Można też stwierdzić, że artefakty wyrażaja lub reprezentuja idee. Relacja reprezentacji zachodzi więc między ideą (modelem) obiektu i realizacją tej idei w realnym świecie, w swoistej technicznej poiēsis. Idee są podstawą wytwarzania artefaktów, są ich intelektualną bazą i ich wzorcami. Idee są wytwarzane dzięki wiedzy pochodzącej z nauk technicznych, np. z biochemii stosowanej, wiedzy medycznej, inżynierii, architektury. Ostatecznym źródłem tej wiedzy są nauki

\footnotetext{
${ }^{28}$ KRĄPIEC 2009.
} 
teoretyczne, źródłem zatem technicyzacji świata i bazą tworzenia artefaktów są nauki podstawowe i generowana $w$ nich wiedza teoretyczna. Nawiasem mówiąc, krytycy nauki oskarżają całą naukę o zmianę ludzkiego świata, w tym jej dziedziny teoretyczne (deskrycypyjno-eksplanacyjne), i się nie mylą. Początkiem i źródłem technicyzacji są nauki teoretyczne, inaczej jeszcze zwane podstawowymi.

Wytwarzanie artefaktu, typu pojetycznego, zaczyna się od projektu mentalnego, uformowanego na podstawie wiedzy naukowej, czerpanej najczęściej z właściwej dla tego projektu nauki teoretycznej. Przedmiot projektu istnieje najpierw potencjalnie, a następnie zostaje zrobiony, wytworzony, zmaterializowany, dodany do przyrody lub - ogólniej — rzeczywistości empirycznej. Materialne przedmioty nauk technicznych nie istnieją, gdy przystępuje się do odpowiednich badań, czyli ściślej: do projektowania nowych obiektów techniki. W pierwszej fazie badań wytwarzane są idee, obiekty potencjalne, niematerialne. Dopiero $\mathrm{w}$ drugiej fazie działalności $\mathrm{w}$ technice, $\mathrm{w}$ fazie poiessis, obiektywne idee uformowane w pierwszej fazie są aktualizowane.

$\mathrm{Z}$ tego, co zostało powiedziane, wynika, że w naukach technicznych reprezentacja jest relacja między idea a odpowiadajacym jej artefaktem lub najczęściej całym zbiorem artefaktów - i już istniejacych, $i$ jeszcze niewytworzonych, a tylko możliwych, w tym sensie, że zaprojektowanych i dopuszczonych przez prawa nauki ${ }^{29}, \mathrm{tj}$. mających ideę czy model. Tak są projektowane np. samochody, samoloty czy lekarstwa. Do zbioru obiektów reprezentujących daną ideę (reprezentowaną) należy zaliczyć zarówno artefakty wytworzone, jak i artefakty tylko potencjalne. Wobec tego zbiór obiektów reprezentujących ideę jest ontologicznie złożony. Należą do niego obiekty dwóch modusów istnienia: i obiekty istniejące aktualnie w rzeczywistości empirycznej, i istniejące potencjalnie, które mają być dopiero wytworzone w przyszłości. Zbiór ten zmienia się w czasie, czyli jest temporalny, niestały, zmienny, rozrasta się, ale i część jego już wytworzonych elementów ulega zużyciu, zniszczeniu. Mówiąc inaczej, artefakty reprezentujące daną ideę (równoważnie, wyrażające ją, wytworzone „z” niej) stanowią zbiór otwarty. Należą do niego artefakty zrealizowane, wytworzone technicznie w formie materialnej odpowiedniki idei, oraz artefakty możliwe, jeszcze niepowstałe. I ta okoliczność, obok innych, komplikuje obraz reprezentacji. Należy zwrócić uwagę, że wskazane komplikacje mają charakter ontologiczny, rzadko rozpatrywany w problematyce reprezentacji $\mathrm{w}$ ogóle. Komplikacją jest to, że obiekty reprezentowane, czyli idee, istnieją w świe-

\footnotetext{
${ }^{29}$ Można tu mówić o możliwości nomologicznej, o niesprzeczności z prawami nauki.
} 
cie niematerialnym, podczas gdy obiekty je reprezentujące istnieją w rzeczywistości materialnej oraz w rzeczywistości potencjalnej.

$\mathrm{Z}$ tego pobieżnego, bardzo niepełnego, na poły hipotetycznego i wymagającego dalszych badań obrazu widać, że reprezentacja w naukach technicznych ma i inny charakter, i inny, można powiedzieć, sens niż reprezentacja $\mathrm{w}$ naukach teoretycznych. W obu typach nauk reprezentowanie jest relacją między wiedzą a rzeczywistością i ten najogólniejszy charakter, wspólny w obu typach nauk, stanowi o jej tożsamości; w obu przypadkach można mówić o reprezentacji. Mówiąc o różnicach, należy podkreślić, że relacja w naukach technicznych jest „odwróceniem” relacji reprezentacji w naukach opisowo-eksplanacyjnych (teoretycznych). W pierwszych idea (model) jest obiektem reprezentującym, natomiast rzeczywistość empiryczna - totalnym przedmiotem reprezentowanym. Natomiast w naukach technicznych obiektem reprezentowanym jest idea (model), natomiast reprezentującym - niezamknięty zbiór artefaktów. To odwrócenie relacji reprezentacji wynika z zasadniczej różnicy między naukami obu typów. W naukach teoretycznych (deskrypcyjno-eksplanacyjnych) celem jest poznawcze ujmowanie rzeczywistości empirycznej; ujmowanie tego, co istnieje, tego, co zastane - przyroda w jej pierwotnej wersji, niezaburzonej ingerencją człowieka. Natomiast w naukach technicznych celem jest projektowanie obiektów (w postaci idei, modeli), które nie istnieją w rzeczywistości empirycznej i które człowiek postanawia powołać do istnienia. Człowiek objawia się tu jako tworzący nowy świat, a nie tylko go poznający; odgrywa rolę podobną do Platońskiego Demiurga.

W naukach podstawowych rolą reprezentacji jest poznawcze ujmowanie (przedstawianie, prezentowanie) świata. W naukach technicznych ludzki podmiot kreuje nowy świat, ale nie dowolnie, nie jak w nieprawdopodobnej fikcji, lecz opierając się na wiedzy naukowej. Reprezentowanie jest tu „odzwierciedlaniem" ludzkich idei w świecie materialnym, który — za sprawą aktualizowania (reprezentowanych) idei — sam się zmienia. Pojetyczne przekształcanie świata na mocy ludzkich idei, czyli ich reprezentowanie typu materialistycznego, jest świadectwem tego — choć zdaję sobie sprawę, że nierozstrzygającym - że technika, jej idee i jej artefakty są własnością człowieka, który najpierw uzyskał wiedzę teoretyczną. Komplikuje to sprawę - podnoszoną przez wielu myślicieli — alienacji człowieka od świata przemienionego technicznie. 


\section{REPREZENTOWANIE A NAUKI TEORETYCZNE VERSUS NAUKI STOSOWANE}

W rozważaniu problemu reprezentacji konieczne jest uwzględnienie tego, że nauki poza aspektami teoretycznymi mają obszary (aspekty) praktyczne, projektujące nowe relacje struktury w badanej dziedzinie. Na przykład ekonomia realizuje i zadania deskryptywno-eksplanacyjne poprzez formowanie wiedzy o dokonywanych procesach gospodarczych zachodzących w praktyce gospodarczej i zadania projektujące - poprzez planowanie (modelowanie) nowych, nieistniejących jeszcze procesów gospodarczych. Ta podwójność charakteru i zadań niektórych nauk empirycznych ma istotne znaczenie dla problemu reprezentacji.

Ważnym aspektem problemu reprezentacji jest podział nauk empirycznych na opisowo-wyjaśniające oraz preskrypcyjne, inaczej nauki stosowane, i efekty tej podwójności zadań, wpływających na charakter nauk, w tym też na ich reprezentację. Większość nauk empirycznych ma dwa typy zadań: opisowo-wyjaśniające i preskrypcyjne, inaczej projektujące (modelujące) nowe typy procesów, obiektów, faktów czy sytuacji, np. ekonomia przedstawia zastane procesy gospodarcze, rynkowe, ale także - opierając się na sformułowanych przez siebie prawach ekonomicznych — projektuje nowe procesy, jeszcze niewystępujące w praktyce rynkowej, a z określonych powodów użyteczne. Zakładając, że wiedza ma postać modeli, można powiedzieć, że ekonomia formułuje modele zastanych procesów lub zjawisk gospodarczych oraz tworzy modele, które przedstawiają procesy potencjalne, wyobrażone, nieistniejące (nieobecne w praktykach ekonomicznych), takie, które byłyby pożądane, np. zwiększyłyby pewne wskaźniki gospodarcze, zintensyfikowałyby wzrost gospodarczy lub zahamowałyby inflację.

Ta podwójność zadań wielu nauk empirycznych (mających aspekt teoretyczny, eksplanacyjny oraz preskrypcyjny) implikuje podwójność relacji reprezentacji w takich naukach. Pisząc o modelach w ekonomii, nie odróżnia się najczęściej dwóch dziedzin ekonomicznych, mających wzajemnie różne zadania, cele, oraz sposoby tworzenia wiedzy i jej charakter. Obie dziedziny — praktyczna, preskrypcyjna, oraz teoretyczna — są z sobą powiązane. Druga czerpie z pierwszej, natomiast pierwsza po wprowadzeniu „w życie” modeli pierwotnie tylko wyobrażanych (np. po wprowadzeniu nowych modeli ekonomicznych) bada je, wyjaśnia ich realizacje w praktyce ekonomicznej i porównuje z projektowanymi modelami. Można zatem powiedzieć, że po fazie pojetycznej $\mathrm{w}$ naukach stosowanych następuje faza 
deskrypcyjno-eksplanacyjna. Nie utożsamiają się one z naukami podstawowymi, gdyż ich przedmiot jest wytworzony, a nie zastany (naturalny), ale mają takie same zadania: opis i wyjaśnienie fragmentów rzeczywistości empirycznej.

Relacja reprezentacji jest $\mathrm{w}$ empirycznych naukach stosowanych inna niż w naukach opisowo-eksplanacyjnych. W naukach stosowanych nie poznaje się obiektów w takim sensie, w jakim poznaje się je w naukach teoretycznych, tzn. nie ujmuje się ich w postaci modeli czy zespołów zdań, odnoszących się do odpowiednich przedmiotów realnie istniejących. Obiekty, którymi nauki stosowane (preskrypcyjne) się zajmują, w ogóle nie istnieją w rzeczywistości empirycznej, np. postulowane zależności ekonomiczne nie są jeszcze wprowadzone do praktyki ekonomicznej, nigdzie nie mamy z nimi do czynienia. Podobnie nie istnieją lekarstwa, które są zaprojektowane, np. jako proste połączenie kilku składników lub wynik określonej syntezy chemicznej. Można tu wysunąć twierdzenie, że obiekty nauk stosowanych istnieją głównie jako obiekty możliwe, ale niezrealizowane. W momencie, gdy zostaną zrealizowane, a ściślej - zmaterializowane, przestają być obiektem zainteresowania tych nauk lub są nim tylko marginalnie. Bada się, czy wytworzone np. stosunki ekonomiczne czy nowe ustanowione legislacyjnie stosunki społeczne są faktycznie zgodne ze swoim potencjalnym odpowiednikiem, czy mają takie właściwości, jak założono w modelu. Krótko mówiąc, rozpatruje się, czy model projektowanych procesów uwzględnił wszystkie czynniki wpływające na te procesy, czy zatem przebiegają one - już urzeczywistnione i wprowadzone do praktyki - tak, jak to przewidywał model (wyprzedzający ich istnienie).

W empirycznych naukach stosowanych sytuacja jest odmienna niż w naukach teoretycznych, gdzie obiekty badań istnieją, a sprawą uczonego jest ich ujęcie w wiedzy, np. przedstawienie ich modeli czy ich opisów w postaci zbiorów zdań. W naukach stosowanych obiekty, które się projektuje, a więc również tworzy ich modele czy opisuje je w postaci zbiorów zdań, nie istnieją w rzeczywistości empirycznej. Można zatem twierdzić, że wiedza o tych obiektach nie ma wartości poznawczych, przede wszystkim nie jest prawdziwa $\mathrm{w}$ sensie korespondencyjnym, ponieważ przedmioty, o których ta wiedza coś mówi, nie istnieją w rzeczywistości empirycznej, lecz istnieją tylko potencjalnie, w jakiejś rzeczywistości wyimaginowanej i możliwej. Wiedza ta staje się ważna, w tym prawdziwa, jeśli obiekty, o których ona mówi, powstaną. Pojawia się więc tu dosyć istotna trudność epistemologiczna, obok ontologicznej. Ponadto trudno twierdzić, że modele (idee) 
wytworzone w nauce stosowanej mają charakter przepisów (dlatego nazwa „preskrypcyjny” jest tu nieco ryzykowna), gdyż jednak przedstawiają one jakieś obiekty - projektowane i nieistniejące, a nie są tylko przepisami, jak działać. To wszystko mnoży komplikacje domagające się wyjaśnienia.

W przypadku nauk stosowanych relacja reprezentacji zachodzi między projektami (modelami) a obiektami projektowanymi, postulowanymi, a następnie relacja ta uwidacznia się między modelem a obiektami powołanymi do istnienia, gdy projekt zostanie zrealizowany. Można by zatem powiedzieć, że mamy dwie różne reprezentacje — w zależności od stanu realizacji projektu. Do czasu, kiedy projekt nie jest zrealizowany, relacja reprezentacji zachodzi między modelem (projektem) a obiektami potencjalnymi, tylko wyimaginowanymi, lecz dopuszczonymi przez prawa nauki. Rzeczywistość ta jest dopiero projektem możliwym nomologicznie, tj. dopuszczonym przez wiedzę daną w naukach empirycznych. Obiektem reprezentowanym jest projekt (model) postulowanych zjawisk, procesów itp., obiektem reprezentującym - te procesy, zjawiska, fakty, które są realizacją projektu. I tu relacja reprezentacji jest odwróceniem tej relacji w naukach teoretycznych, podstawowych, inaczej jeszcze: deskrypcyjno-eksplanacyjnych.

Relacja reprezentacji jest $\mathrm{w}$ naukach technicznych podobna do relacji w stosowanych naukach empirycznych, takich jak np. socjologia, politologia, ekonomia. W naukach technicznych wykorzystuje się do celów praktycznych wiedzę teoretyczną uzyskaną w naukach przyrodniczych (np. mechanikę Newtona, mechanikę kwantową).

W obu typach nauk - empirycznych stosowanych i technicznych mamy do czynienia $\mathrm{z}$ wymyślaniem nowych obiektów, $\mathrm{z}$ niematerialnym tworzeniem (intelektualnym) nowych rzeczywistości i z ich materializowaniem. Idee, modele, projekty transformowane są w obiekty materialne, $\mathrm{w}$ procesy zachodzące $\mathrm{w}$ materialnej rzeczywistości.

\section{REPREZENTACJA W NAUKACH INFORMATYCZNYCH}

W naukach informatycznych (komputerowych) obraz reprezentacji wydaje się pod pewnymi względami podobny do reprezentowania w naukach technicznych i empirycznych naukach stosowanych. Są jednak i różnice: specyfiką przedmiotu tych nauk jest wirtualność. I tu pojawia się trudność, ponieważ status ontyczny obiektów wirtualnych w naukach komputerowych nie jest rozpoznany, a nie można przenieść równobrzmiącego pojęcia z fizyki 
— wydaje się, że w obu typach sytuacji chodzi o coś innego. Podobieństwo polega na tym, że w naukach komputerowych, podobnie jak w technicznych i empirycznych stosowanych, tworzy się najpierw modele, a następnie wytwarza na ich podstawie obiekty, które wprawdzie nie należą do przyrody, ale w jakimś sensie istnieją, np. jako obiekty kulturowe (memy), jako obiekty idei w sferze świadomości zbiorowej. Rodzi się od razu pytanie o problem ontycznego statusu obiektów wirtualnych ${ }^{30}$. I to stwierdzenie wyczerpuje w zasadzie przydatną wiedzę, którą można by się posiłkować, badając problem reprezentacji w naukach informatycznych ${ }^{31}$.

Inną trudnością, która się tu wyłania, jest dość niezawansowany stan dociekań, czym w ogóle jest informatyka ${ }^{32}$. Ponadto ten niezaawansowany stan badań nauk informatycznych (poza teorią informacji, która przynajmniej w niektórych jej ujęciach znajduje się na styku nauk informatycznych) jest zaskakujący, ponieważ komputeryzacja świata ma niewyobrażalne wręcz znaczenie dla ludzkiego życia i jego zmian w ostatnich dziesięcioleciach.

Najkrócej rzecz ujmując, w naukach empirycznych reprezentowanie polega na formowaniu wiedzy o zastanych obiektach, na dopasowywaniu

${ }^{30}$ Istniejące koncepcje obiektów wirtualnych nie są ani wystarczające, ani zadowalające. Zob. np. BONDECKA-KRZYKOWSKA 2012, 139-153.

${ }^{31}$ Za wskazanie przykładu rozszerzenia obszaru refleksji filozoficznej dotyczącego symulacji komputerowych w obrębie reprezentacji w naukach informatycznych dziękuję Recenzentowi pracy. Niewątpliwie symulacje komputerowe (numeryczne lub obliczeniowe) odgrywają ważną rolę nie tylko w różnych dyscyplinach naukowych, ale także odgrywają ważną rolę społeczną — począwszy od dostarczania prognoz pogody ułatwiających codzienne funkcjonowanie, aż po symulacje prognozujące zmiany klimatu w skali globalnej (WINSBERG 2019). To narzędzie badawcze jest używane nie tylko w naukach ścisłych (przede wszystkim do wirtualnych eksperymentów), ale również — co może dziwić - w filozofii. Znane są próby symulacji komputerowych koncepcji metafizycznych, epistemicznych oraz etycznych dokonane przez Roberta Janusza $(2002,2007)$. Interesującą rolę symulacji komputerowych jako źródło nowych metafor filozoficznych (zgodnie z koncepcją technologii definiującej zaproponowaną przez filozofa techniki D. J. Boltera) przedstawił Paweł Polak. Przeprowadzone przez niego analizy prowadzą do ważnego poznawczo wniosku, mówiącego, że możemy obserwować istotne zmiany w metodologii filozofii wskazując, że symulacje komputerowe mogą być jednym z nowych narzędzi analitycznych filozofii (PoLAK 2020). Znaczenie symulacji komputerowych w metodologii nauki oraz jej związków z praktyką laboratoryjną można także znaleźć w rozprawie Sławomira Leciejewskiego (2013).

${ }^{32}$ Odpowiedzi na pytanie nie ułatwia obowiązująca terminologia. W języku polskim termin „informatyka” najczęściej jest tłumaczony na język angielski jako computer science. Istnieje także drugi termin, informatics, thumaczony na język polski jako „informatyka”. Encyklopedia $P W N$ podaje definicję informatyki jako „dyscypliny naukowej zajmującej się przetwarzaniem informacji z użyciem komputerów” (https://encyklopedia.pwn.pl/haslo/3914698/informatyka.html (dostęp 25.05.2019). Informatyka często jest opisywana jako studiowanie algorytmicznych procesów wytwarzających, opisujących, przekształcających i składujących informacje. Zob. DENNING 2000; RAPAPORT 2019. 
wiedzy do rzeczywistości empirycznej. Natomiast w dziedzinie informatyki formułuje się wiedzę, w postaci programów komputerowych, która generuje obiekty wirtualne - obiekty te nie istnieją, gdy programy są tworzone; programy te powołują obiekty wirtualne do istnienia. Zasadnie jest przyjąć, że $\mathrm{w}$ informatyce obiekty wirtualne reprezentują ujęte w postaci programów komputerowych pomysły, projekty itp. programistów: są ich przedmiotowymi „odzwierciedleniami”, przedmiotowymi realizacjami wiedzy w rzeczywistości wirtualnej, niematerialnej. Odwrócenie relacji reprezentacji w informatyce względem tej relacji w naukach empirycznych polega na tym, że w pierwszym przypadku obiekty wirtualne są reprezentacjami wiedzy, ściślej: obiektami, które reprezentują projekty, programy komputerowe, natomiast $\mathrm{w}$ drugim przypadku to wiedza reprezentuje rzeczywistość empiryczną. Ściślej rzecz biorąc, w informatyce występują obie odmiany reprezentacji: obiekty wirtualne, już powołane do istnienia, są z kolei reprezentowane przez programy komputerowe w sposób analogiczny do tego występującego w naukach empirycznych. Reprezentacja odwrócona jest jednak w obszarze informatyki istotniejsza - specyficzna dla tej dziedziny i dla generowanych w niej rzeczywistości wirtualnych. Reprezentowanie w naukach komputerowych polega zatem na tworzeniu przedmiotowych odpowiedników uformowanej wiedzy w postaci programów komputerowych, na wytwarzaniu $\mathrm{z}$ wiedzy nowych rzeczywistości. Tworzy się niematerialne obiekty wirtualne, dopasowując je do treści zawartych w programach komputerowych. Fakt sformowania wiedzy i uznanie jej korespondencyjnej prawdziwości gwarantuje istnienie obiektów, do których ta wiedza się odnosi - poprzez zachodzenie relacji korespondencji. Tu mamy do czynienia $\mathrm{z}$ istnieniem niematerialnym, ale rzeczywistym - skoro uznaje się programy komputerowe za prawdziwe. Reprezentowanie „odwrócone” ma charakter tworzenia obiektów - odzwierciedlających pojęcia i treści programu komputerowego. Zarazem już istniejący, powołany do istnienia obiekt wirtualny jest obrazowany w odpowiednim programie komputerowym, który go powołał „do życia”, a więc jest on reprezentowany w sposób obowiązujący w naukach empirycznych ${ }^{33}$.

${ }^{33}$ Zob. MAZUREK 2020. 


\section{PODSUMOWANIE}

O ile przyjąć naszkicowaną interpretację reprezentowania w naukach stosowanych i technicznych oraz prawdopodobnie, lecz z wieloma niepewnościami, hipotetycznie, informatycznych, to okazuje się, że relacja reprezentowania jest w nich „odwrócona” względem tej relacji w naukach deskrypcyjno-eksplanacyjnych (teoretycznych). To odwrócenie jest związane z różnicami między charakterem nauk wymienionych typów. W naukach deskrypcyjno-eksplanacyjnych chodzi o generowanie wiedzy o zastanej dziedzinie rzeczywistości, która istnieje, gdy przystępuje się do badań. W pozostałych naukach głównym zadaniem i operacją jest wytwarzanie nowych obiektów, nieistniejących, gdy podejmuje się odnoszące do nich przedsięwzięcia badawcze. Ta odrębność zadań decyduje o charakterze nauk, w tym o relacji między wiedzą a rzeczywistością; relacja ta jest różna w różnych naukach. W stosowanych naukach deskrypcyjno-eksplanacyjnych obiekt reprezentowany to idea, wiedza (model lub zbiór zdań), a obiekt reprezentujący (ową ideę) - to obiekt materialny, artefakt, lub obiekt potencjalny, także wirtualny. W stosowanych naukach empirycznych pojawiają się obiekty możliwe, niematerialne, wirtualne, w naukach informatycznych zaś są one wyłącznymi przedmiotami tych nauk. Świat nauki to w dużym obszarze świat wytworzony, efekt specyficznego poiēsis, obecnego nie tylko - jak się okazuje - w sztuce. Artefakty, byty możliwe, obiekty wirtualne ${ }^{34} \mathrm{w}$ coraz większym stopniu zaludniają nie tylko ludzki świat życia: tworzą antropo$\operatorname{cen}^{35}$, ale i świat niematerialny, równie dla człowieka ważny jak jego materialne otoczenie. Idee formowane w nauce są motorem zmian ludzkiego świata, i materialnego, i duchowego, inaczej zbiorowej świadomości.

$\mathrm{W}$ porównaniu $\mathrm{z}$ empirycznymi naukami teoretycznymi $\mathrm{w}$ pozostałych naukach zmienia się więc rola wiedzy i przedmiotu: obiekt reprezentowany to idea, artefakt zaś, obiekt materialny, to obiekt, który reprezentuje naszą ideę. Natomiast $w$ naukach deskrypcyjno-eksplanacyjnych obiekt reprezentowany jest przedmiotem w przyrodzie lub społeczeństwie, a wiedza o nim jest jednostką reprezentującą.

\footnotetext{
${ }^{34}$ Zob. KiePas, SuŁKowsKa i WoŁeK 2009; por. np. LAtawiec 2004, 279-291.

${ }^{35}$ Pojęcie ,antropocen” (era człowieka)m określające współczesną epokę geologiczną zdominowana przez człowieka, zostało zaproponowane przez biologa Eugene'a F. Stoermera oraz chemika atmosfery Paula J. Crutzena w 2000 r. Ich zdaniem początki antropocenu wiązać należy z wynalezieniem maszyny parowej przez Jamesa Watta (1763), symbolizującej początek rewolucji przemysłowej. Zob. np. STROMBERg 2013.
} 
W empirycznych naukach stosowanych oraz w naukach technicznych i prawdopodobnie komputerowych, w sumie w naukach pojetycznych, reprezentowanie polega na dopasowywaniu wytworów (materialnych lub nie) do naszych wytworzonych idei, de facto polega na materialnym aktualizowaniu tych idei, natomiast $\mathrm{w}$ teoretycznych naukach empirycznych to idee (modele) dopasowuje się do zastanych obiektów materialnych. Druga różnica polega na ontycznym statusie przedmiotów tych nauk. Coraz większą rolę w nauce odgrywa wytwarzanie, „robienie”, kreowanie przedmiotów, także niematerialnych, a nie poznawcze ujmowanie tych przedmiotów, które są od nas niezależne. W naukach pojetycznych obiekt reprezentujący wiedzę - czyli idee odnoszące się do tego, co nie istnieje, co jest tylko możliwe - jest zarazem naszym wytworem i w efekcie zmienia rzeczywistość zastaną. Podobny charakter - co może wydawać się paradoksalne — ma reprezentowanie w sztuce, będące notabene jej głównym atrybutem.

Ujęcie problemu reprezentowania w naukach stosowanych, technicznych i informatycznych kieruje nas do poziomu ontologicznego. W ujmowaniu problemu reprezentacji pojawiają się bowiem obiekty niebędące „standardowymi" przedmiotami rzeczywistości empirycznej (przyrody czy społeczeństwa). Są to wytwory poiessis, obiekty „zrobione” i materialne, i niematerialne (wirtualne). Są one niesłychanie interesujące $\mathrm{z}$ ontologicznego punktu widzenia, a także, w konsekwencji, z epistemologicznego, a nawet antropologicznego. Życie w antropogenezie bowiem to życie w rzeczywistości „sztucznej”, w coraz większym stopniu tracącej związek z pierwotną przyrodą, to życie wśród własnych wytworów, które stają się człowiekowi obce, niezrozumiałe i które, pojawiając się nieustannie, niszczą u ludzi poczucie stabilności ich otoczenia.

Należy tu dodać, że status — jako bytów — materialnych artefaktów wytwarzanych $\mathrm{w}$ technologiach oraz obiektów wirtualnych wytwarzanych za sprawą operacji informatycznych jest wątpliwy, m.in. z tego względu, że atrybutem bytów jest autonomiczność, a obiekty, o których mowa, są przynajmniej w genezie całkowicie zależne od człowieka. Rodzą się tu istotne pytania: Czy autonomizują się one $\mathrm{w}$ ich istnieniu? Czy zautonomizowane mogą wpływać na człowieka, który je powołał do istnienia, a nawet mu zagrażać, dominować, jak mówią liczne przepowiednie i diagnozy współczesnych literatów, futurystów, uczonych, a nawet filozofów?

Wszystkie podnoszone kwestie pokazują konieczność przywołania na powrót kategorii ontologicznych, wykluczanych ze współczesnej filozofii nauki w rozważaniach epistemologicznych. Problemy te są też istotne w sfe- 
rze filozofii człowieka, gdyż bez wątpienia człowiek obecnie egzystuje w świecie coraz bardziej sztucznym, technologiczno-informatycznym w świecie artefaktów i obiektów wirtualnych, w antropocenie, który w sprzężeniu zwrotnym zmienia człowieka. Trzeba poznać głębokie warstwy tego świata, nie tylko po to, aby poznać nasz habitat, ale także po to, aby zrozumieć dokonujące się przemiany ludzkiej istoty.

Niektóre przedstawione w tym tekście hipotezy i rozstrzygnięcia wyłoniły się i/lub skrystalizowały w dyskusjach z Prof. Małgorzatą Czarnocką. Chciałbym jej podziękować za tę pomoc.

\section{REFERENCJE}

Bailer-Jones, Daniela. 2009. Scientific Models in Philosophy of Science. Pittsburg: University of Pittsburgh Press.

Barberousse, Anouk, i Pascal Ludwig. 2009. „Models as Fictions”. W: Fictions in Science. Philosophical Essays on Modeling and Idealization, red. Mauricio Suárez, 56-73. New York: Routledge.

Boesch, Brandon. 2018. Scientific Representation and Human Action. University of South Carolina. University Libraries. Scholar Commons. Dostęp 06.10.2019. https://scholarcommons.sc.edu/ cgi $/$ viewcontent.cgi? article $=5589 \&$ context $=$ etd.

BONDECKA-KRZYKOwSKA, Izabella. 2012. „Uwagi na temat ontologii wirtualnej rzeczywistości”. Filozofia Nauki 4: 139-153.

Callender, Craig, i Jonathan Cohen. 2005. „There Is No Special Problem about Scientific Representation". Theoria 55: 67-85. DOI: https://doi.org/10.1387/theoria.554.

Cartwright, Nancy, Towfic Shomar, i Mauricio SuÁrez. 1995. „The Tool Box of Science: Tools for the Building of Models with a Superconductivity Example". W: Theories and Models in Scientific Processes, red. William E. Herfel, Władysław Krajewski, Ilkka Niiniluoto i Ryszard Wójcicki, 137-149. Amsterdam, Atlanta: Rodopi.

CArtwright, Nancy. 1983. How the Law of Physics Lie. Oxford: Oxford University Press.

CARTwright, Nancy. 1999. „Models and the Limits of Theory: Quantum Hamiltonians and the BCS Model of Superconductivity". W: Models as Mediators, red. Mary S. Morgan i Margaret Morrison, 241-281. Cambridge: Cambridge University Press.

Cartwright, Nancy. 1999. The Dappled World. A Study of the Boundaries of Science. Cambridge: Oxford University Press.

Contessa, Gabriele. 2007. Representing Reality: The Ontology of Scientific Models and Their Representational Function. London: University of London. 
Coopmans, Catelijne, Janet Vertesi, Michael Lynch, i Steve Woolgar. 2014. Representation in scientific practice revisited. Cambridge, MA: MIT Press.

Czarnocka, Małgorzata. 2009. Droga do koncepcji prawdy symbolicznej. Warszawa: Wydawnictwo IFiS PAN.

CZARNOCKA, Małgorzata. 2019. „O potrzebie metateoretycznej zmiany w filozofii nauki na przykładzie problemu modeli i reprezentacji”. W: Między filozofia a chemia. Księga Jubileuszowa dla Profesora Pawła Zeidlera, red. Jarosław Boruszewski, Radosław Kazibut, Sławomir Leciejewski, Tomasz Rzepiński i Zbigniew Tworak, 65-82. Poznań: Wydawnictwo Naukowe UAM.

Da Costa, Newton, i Steven French. 2003. Science and Partial Truth: A Unitary Approach to Models and Scientific Reasoning. Oxford: Oxford University Press.

Denning, Peter J. 2000. „Computer Science: The Discipline” W: Encyclopedia of Computer Science, red. Anthony Ralston i David Hemmendinger. Dostęp 06.10.2019. http://denning institute.com/pjd/PUBS/ENC/cs99.pdf.

Franssen, Maarten, Peter Kroes, Thomas Reydon i Pieter E. Vermaas (red.). 2014. Artefact Kinds. Ontology and the Human-Made World. Switzerland: Springer International Publishing.

Franssen, Maarten, i Peter Kroes. 2014. „Artefact Kinds, Ontological Criteria, and Forms of Mind-Dependence". W: Artefact Kinds. Ontology and the Human-Made World, red. Franssen, Maarten, Peter Kroes, Thomas Reydon i Pieter E. Vermaas. Switzerland: Springer International Publishing, s. 63-84. DOI: 10.1007/978-3-319-00801-1_5.

Franssen, Maarten, Gert-Jan LoKhorst, i Ibo van de Poel. 2018. Philosophy of Technology. W: The Stanford Encyclopedia of Philosophy (Fall 2018 Edition), red. Edward N. Zalta. Dostęp 06.10.2019. https://plato.stanford.edu/entries/technology/.

FRIGG, Roman. 2002. „Models and Representations: Why Structures are not Enough”. W: Centre for Philosophy of Natural and Social Sciences. Measurement in Physics and Economics Project Discussion Paper Series, DP MEAS 25/02, 1-42. London: London School of Economics. Roman Frigg. Dostęp 05.05.2021. http://www.romanfrigg.org/writings/Models _and_Representation.pdf.

FrIGG, Roman. 2010. „Fiction and Scientific Representation”. W: Beyond Mimesis and Convention. Representation in Art and Science, red. Roman Frigg, Matthew C. Hunter, 97138. Berlin, New York: Springer. Roman Frigg. Dostęp 05.05.2021. http://www.roman frigg.org/writings/Fiction_and_Scientific_Representation.pdf

GalimberTi, Umberto. 2009. „Man in the age of technology.” Journal of Analytical Psychology 54, 1: 3-17. DOI: https://doi.org/10.1111/j.1468-5922.2008.01753.x.

GeHLen, Arnold. 1980. Man in the age of technology. New York: Columbia University Press.

GiERE, Ronald N. 1988. Explaining Science. A Cognitive Approach. Chicago: University of Chicago Press.

GoczyŁa, Krzysztof. 2011. Ontologie w systemach informatycznych. Warszawa: Akademicka Oficyna Wydawnicza EXIT.

Hardt, Łukasz. 2014. „Modele, metafory i teoria ekonomii”. Diametros 41: 13-37. DOI: 10.13153 /diam.41.2014.650

HARDt, Łukasz. 2016. „On Similarities in Modelling and Metaphorizing Economic Phenomena”. Studia Metodologiczne 36: 147-174. DOI: 10.14746/sm.2016.36.8.

HaRdT, Łukasz. 2018. „Economic Models and Ceteris Normalibus Laws”. Studia Ekonomiczne 1-2: 41-70. 
Hartmann, Stephan. 1995. „Models as a Tool for Theory Construction: Some Strategies of Preliminary Physics". W: Theories and Models in Scientific Processes red. William E. Herfel, Władysław Krajewski, Ilkka Niiniluoto i Ryszard Wójcicki, 49-67. Amsterdam, Atlanta: Rodopi.

HiLipen, Risto. 2018. „Artifact”. W: The Stanford Encyclopedia of Philosophy (Summer 2018 Edition), red. Edward N. Zalta. Dostęp 06.10.2019. https://plato.stanford.edu/archives/ sum2018/entries/artifact.

Humphreys, Paul, i Cyrille Imbert (red). 2013. Models, Simulations, and Representations. New York: Routledge.

JANUSZ, Robert. 2002. Program dla Wszechświata: filozoficzne aspekty języków obiektowych, Kraków: Wydawnictwo WAM.

JANUSZ, Robert. 2007. „O metodach wirtualnych w paradygmacie obiektowym”. Zagadnienia Filozoficzne w Nauce 41: 125-131.

Kiepas, Andrzej, Mariola SuŁkowska i Magdalena WoŁek (red.). 2009. Człowiek a światy wirtualne. Katowice: Wydawnictwo Uniwersytetu Śląskiego.

KRAJEwSKI, Władysław. 1996. „Różne pojęcia modelu w nauce”. Zagadnienia Naukoznawstwa 130, $\mathrm{nr}$ 4: 445-454.

Krąpiec, Mieczysław A. 2009. „Akt i możność”. W: Powszechna Encyklopedia Filozofii, t. 1, red. Andrzej Maryniarczyk. Polskie Towarzystwo Tomasza z Akwinu. Dostęp 06.10. 2019. http://www.ptta.pl/pef/pdf/a/aktim.pdf.

Latawiec, Anna. 2004. „Uwagi w sprawie wirtualności”. Studia Philosophiae Christianae 40, nr 2: 279-291.

LECIEJEWSKI, Sławomir. 2013. Cyfrowa rewolucja $w$ badaniach eksperymentalnych: studium metodologiczno-filozoficzne, Poznań: Wydawnictwo Naukowe UAM.

MAZUREK, Mariusz. 2017. Modele w filozoficznych koncepcjach nauki. Warszawa: IFiS PAN

MAzUReK, Mariusz. 2020. „O obiektach wirtualnych”. Filozofia i Nauka. Studia Filozoficzne i Interdyscyplinarne 8: 137-154. DOI: https://doi.org/10.37240/FiN.2020.8.1.5.

Morgan, Mary, Tarja KnuUttila. 2012. „Models and Modelling in Economics”. W: Handbook of the Philosophy of Economics, red. Uskali Mäki, 49-87. North Holland: Elsevier Science.

Morgan, Mary, i Margaret Morrison. 1999. „Models as Mediating Instruments”. W: Models as Mediators. Perspectives on Natural and Social Science, red. Mary Morgan i Margaret Morrison, 10-37. Cambridge: Cambridge University Press.

Nersessian, Nancy J. 1999. „Model-based Reasoning in Conceptual Change”. W: Model-based Reasoning in Scientific Discovery, red. Lorenzo Magnani, Nancy J. Nersessian i Paul Thagard, 5-22. New York: Kluwer/Plenum.

PitT, Joseph C. 1999. Thinking About Technology: Foundations of the Philosophy of Technology. New York: Seven Bridges Press.

Polak, Paweł. 2020. „Modelowanie komputerowe w filozofii - uwagi metodologiczne”. Filozofia i Nauka. Studia Filozoficzne i Interdyscyplinarne 8: 203-212. DOI: https://doi.org/ 10.37240/FiN.2020.8.1.9.

Portides, Demetris. 2011. „Seeking Representations of Phenomena: Phenomenological Models” Studies in History and Philosophy of Science 42, 2: 334-341.

Preston, Beth. 2018. „Artifact”. W: The Stanford Encyclopedia of Philosophy (Fall 2018 Edition), red. Edward N. Zalta. Dostęp 06.10.2019. https://plato.stanford.edu/archives/fall2018/ entries/artifact (06.10.2019). 
RAPAPORT, William J. 2019. „Philosophy of Computer”. University at Buffalo. Department of Computer Science and Engineering. William J. Rapaport, Associate Professor Emeritus. Dostęp 06.10.2019. https://cse.buffalo.edu/ rapaport/ Papers/phics.pdf.

Schummer, Joachim. 2001. „Aristotle on technology and nature”. Philosophia Naturalis 38: 105120. Joachim Schummer. Dostęp 05.05.2021. http://joachim schummer.net/papers/2001_ Aristotle_PhilNat.pdf.

Stromberg, Joseph. 2013. „What Is the Antropocene and Are We in It?” Smithsonian Magazine. https://www.smithsonianmag.com/science-nature/what-is-the-anthropocene-and-are-we-init- $164801414 /(06.10 .2019)$.

SuÁrez, Mauricio. 2003. „Scientific Representation: Against Similarity and Isomorphism”. International Studies in the Philosophy of Science 17, no. 3: 225-244. DOI: https://doi.org/ 10.1080/0269859032000169442.

SuÁrez, Mauricio. 2010. „Scientific Representation”. Blackwell's Philosophy Compass 5: 91101. DOI: https://doi.org/10.1111/j.1747-9991.2009.00261.x.

Thagard, Paul. 2005 2. Mind. Introduction to Cognitive Science. Cambridge, Massachusetts, London: MIT Press.

Thomasson, Amie. 2007. „Artifacts and Human Concepts”. W: Creations of the Mind: Theories on Artifacts and Their Representation, red. Eric Margolis i Stephen Laurence. Oxford: Oxford University Press, s. 52-73.

Van Fraassen, Bas. 2008. Scientific Representation: Paradoxes of Perspective. Oxford: Oxford University Press.

Winsberg, Eric. 2019. „Computer Simulations in Science”. W: The Stanford Encyclopedia of Philosophy (Winter 2019), red. Edward N. Zalta. Dostęp 03.10.2020. https:// plato. stanford.edu/ archives/win2019/entries/simulations-science.

Wóscicki, Ryszard. 1994. Theories and Theoretical Models. W: Patrick Suppes: Scientific Philosopher. Vol. 1. Probability and Probabilistic Causality, red. Paul Humphreys, 125149. Dordrecht: Kluwer Academic Publishers.

Woolgar, Steve. 2002. Virtual society? Technology, Cyberbole, Reality. Oxford-New York: Oxford University Press.

Zahorodna, Katarzyna. 2015. Problem reprezentacji umystowych $w$ rozszerzonych systemach poznawczych. Wrocław: Wydawnictwo Fundacji „Projekt Nauka”.

Zeidler, Paweł. 2013. Models and Metaphors as Research Tools in Science. A Philosophical, Methodological and Semiotic Study of Science. Münster-Berlin-Wien-Zürich: LIT Verlag.

\section{PROBLEM REPREZENTACJI W NAUCE - OBSZARY NIEZBADANE}

\section{Streszczenie}

Celem artykułu jest, znacznie wszechstronniejsze niż czyni się to dotychczas w filozofii nauki, przebadanie relacji reprezentacji $\mathrm{w}$ nauce oraz $\mathrm{w}$ jej zastosowaniach $\mathrm{w}$ praktyce. Analizowany jest nie tylko problem reprezentowania w naukach empirycznych (do nich ograniczone są analizy w literaturze przedmiotu), ale także w naukach technicznych oraz w naukach informatycznych łącznie $\mathrm{z}$ ich zastosowaniami w praktyce. Uwzględnienie zastosowań praktycznych nauk technicznych i informatycznych jest niezbędne, ponieważ nauki te $-\mathrm{w}$ przeciwieństwie 
do nauk empirycznych, o pierwotnych celach poznawczych - są naukami praktycznymi, nastawionymi na generowanie rozwiązań, które mają zastosowanie w praktyce pozabadawczej. Różnice w relacjach reprezentowania, typach obiektów reprezentowanych i reprezentujących pokazują najgłębszą różnicę w naturach tych nauk.

Słowa kluczowe: reprezentacja w naukach empirycznych; podobieństwo; reprezentacja w naukach technicznych; poiesis; artefakt; reprezentacja w naukach informatycznych; obiekt wirtualny

\section{THE PROBLEM OF REPRESENTATION IN SCIENCE: UNEXPLORED AREAS}

\section{Su m m a ry}

The aim of the article is - notably more comprehensive than so far performed in the philosophy of science - analysis of representing in science as well as in its practical applications. The analysis shall consider not only the problem of representation in empirical sciences (to those sciences are limited investigations of representing in philosophy), but also in technical and computer sciences, including their practical applications. The account of practical applications of sciences technical and computer sciences is essential as they - as opposed to empirical sciences with original cognitive purposes - are mostly practical and oriented towards generating results which are useful in extra-scientific practice. The differences in relations of representing, types of represented and representing objects depict the most profound difference in natures of these sciences.

Keywords: representation in empirical sciences; similarity; representation in technical sciences; poiesis; artifact; representation in IT sciences; virtual object.

Information about Author: Mariusz Mazurek, $\mathrm{PhD}$ - Institute of Philosophy and Sociology of the Polish Academy of Sciences; address for correspondence: ul. Nowy Świat 72, 00-330 Warszawa; e-mail: mmazurek@ifispan.edu.pl; ORCID: https://orcid.org/0000-0002-9646-6897. 